\title{
Intracerebral transplantation for neurological disorders. Lessons from developmental, experimental, and clinical studies
}

\author{
Alexandra Benchoua $^{1 *}$ and Brigitte Onteniente ${ }^{2,3}$ \\ 1 I-Stem, CECS, Evry cedex, France \\ 2 I-Stem, INSERM UMR 861, Evry cedex, France \\ ${ }^{3}$ Université Evry-Val d'Essonne, Evry cedex, France
}

Edited by:

Afsaneh Gaillard, Université de

Poitiers, France

Reviewed by:

Shaoyu Ge, SUNY Stony Brook, USA

Mohamed Jaber, INSERM,

University of Poitiers, France

\section{*Correspondence:}

Alexandra Benchoua, I-Stem, CECS,

5 rue Henri Desbruères, F-91030

Evry cedex, France.

e-mail: abenchoua@istem.fr
The use of human pluripotent stem cells (PSCs) for cell therapy faces a number of challenges that are progressively answered by results from clinical trials and experimental research. Among these is the control of differentiation before transplantation and the prediction of cell fate after administration into the human brain, two aspects that condition both the safety and efficacy of the approach. For neurological disorders, this includes two steps: firstly, the identification of the optimal maturation stage for transplantation along the continuum that transforms PSCs into fully differentiated neural cell types, together with the derivation of robust protocols for large-scale production of biological products, and, secondly, the understanding of the effects of environmental cues and their possible interference with transplanted cells commitment. This review will firstly summarize our knowledge on developmental processes that have been applied to achieve robust in vitro differentiation of PSCs into neural progenitors. In a second part, we summarize results from experimental and clinical transplantation studies that help understanding the dialogue that establishes between transplanted cells and their host brain.

Keywords: embryonic stem cells, induced pluripotent stem cells, neurogenesis, brain plasticity, transplantation
Pluripotent stem cells (PSCs) are defined by the ability to selfrenew indefinitely in a controlled environment and to form cells of all organs after guided (in vitro) or natural (in vivo) differentiation. PSC include embryonic stem cells (ESC; Thomson et al., 1998) and induced pluripotent SC (iPSC; Takahashi and Yamanaka, 2006). Human (h) iPSC and hESC share the same ability to differentiate along the neural lineage (Karumbayaram et al., 2009) and are considered appropriate cell sources for stem cell (SC) therapy in neurological disorders. In some reports, hiPSC have shown a greater variability in neural differentiation properties than hESC (Hu et al., 2010). However, recent technical improvements have reduced these variations (Chambers et al., 2009; Hu et al., 2010), emphasizing the importance of environmental cues in neural commitment. The definition of the ideal therapeutic product for intracerebral transplantation is also restricted by the fact that, on the one hand, fully differentiated neurons do not survive transplantation and, on the other hand, undifferentiated PSC usually form teratoma after transplantation if not rejected by the recipient immune system. The optimal therapeutic product is a still ill-defined intermediate, described as a "neural stem cell" (NSC), a "neural precursor cell" (NPC), or a neural progenitor, without accurate characterization of each phenotype.

The brain contains billions of neurons that connect one with another in complex networks and are grouped according to anatomical and functional criteria into hundreds of sub-populations. Ideally, cell replacement therapy should aim at transplanting neurons with phenotype(s) identical to the one(s) destroyed by the pathology or the insult. This requirement varies according to the disorder (Rossi and Cattaneo, 2002). Neurodegenerative diseases involve progressive destruction - at least in the first steps of the disease-of a main neuronal population, e.g., ventral telencephalic dopaminergic neurons in Parkinson's disease, striatal GABAergic medium spiny neurons in Huntington's disease, or motoneurons in amyotrophic lateral sclerosis. Besides neuronal populations, demyelinating diseases such as multiple sclerosis would require the replacement of glial cells, namely oligodendrocytes that share with neurons and astrocytes a common progenitor. In these cases, the replacement of a single cell type would theoretically be sufficient to limit the clinical consequences of the disease, and efforts have been put on the development of differentiation protocols aimed at increasing the yield of the corresponding population (Perrier et al., 2004; Keirstead et al., 2005; Shin et al., 2005). In contrast, acute brain lesions or diffuse, aspecific, degeneration, as found after trauma, stroke, genetic diseases with stroke, or vascular dementias, are characterized by the destruction of heterogeneous cell populations with variable identities according to the lesion site. The identification of the final therapeutic product is thus less clear-cut and might even include neural and non-neural cell populations, such as mesoderm-derived microglia and blood vessel-forming cells.

After transplantation, NSC, NPC, or progenitors, can be differentially affected by the changes that abruptly occur in their environment. Defining the role of the environment on the fate of transplanted neural cells is a highly demanding task that has been approached in several disease models and is still rudimentary. 
This goal might never totally be reached if one considers the importance of the temporal dimension and related constant adaptation of the cerebral milieu during the course of a disease. These are particularly crucial in acute brain lesions with breaches in the blood-brain barrier that lead to a profound and rapidly evolving transformation of the parenchymal milieu.

In conclusion, the development of a bioproduct for PSC therapy relies, firstly, on their propensity to be instructed before transplantation and, secondly, to their reaction to dramatic changes in environmental cues after transplantation. The development of efficient grafts requires (1) the definition of needed cell type(s) according to the pathology, (2) the definition of the intermediate cell type able to sustain transplantation, and (3) the elaboration of protocols amenable to standardization for large-scale clinical application, including amplification and storage steps. Here we discuss how our knowledge from embryogenesis has been applied to PSC to develop neural intermediates with clinical relevance, and how experimental and clinical studies can help us understanding the modifications of pre-transplantation commitment by the lesioned brain environment.

\section{THE FIRST STEPS OF NEURAL COMMITMENT: LESSONS FROM EMBRYOGENESIS \\ FROM PLURIPOTENCY TO NEUROPOTENCY}

Obtaining specific neuronal or glial populations has to proceed through two essential steps. Firstly, pluripotent cells must be committed into the neural lineage to the first population of neural progenitors found in the neural plate, the neuro-epithelial cells. Secondly, still primitive and plastic neuro-epithelial cells must be regionally patterned to restrict their potential into the requested type of neuron or glial cell.

Until recently, most of the neural induction protocols used for the conversion of PSC into neuro-epithelial cells relied on the formation of embryonic bodies or on the co-culture of PSC with mesenchymal stromal cell lines. Stromal cell lines, such as the PA6 or MS-5 murine lines, have strong neural-inducing properties (Kawasaki et al., 2000). Using these methods, human PSCs may be coaxed along the neural lineage to differentiate into a population of bipolar neuro-epithelial cells that express the main markers of the neural tube, Pax6 and Sox1 (Perrier et al., 2004; Watanabe et al., 2005). This organization, named "rosette," morphologically and molecularly mimics the developing neural tube (Zhang et al., 2001; Ying et al., 2003) (Figure 1). Embryoid bodies and rosette-related strategies have considerable drawbacks, including poorly defined culture conditions and concomitant production of undesired cell types. The later requires an additional step of cell sorting to obtain more homogenous populations. This procedure also requires the use of cells and components from animal origin. A step forward to clinical application was made by Lowell and collaborators, who demonstrated that hPSC can adopt a neural lineage in adherent, feeder-free, monolayer culture with a fully defined medium (Lowell et al., 2006). Still, this "default" differentiation protocol lacked efficacy and did not solve the problem of heterogeneity, leading to a mixture of Pax6/Sox1 neuro-epithelial cells and of still undifferentiated Oct4/TRA1-60positive cells that remained refractory to induction. This indicated that additional developmental cues had to be identified and
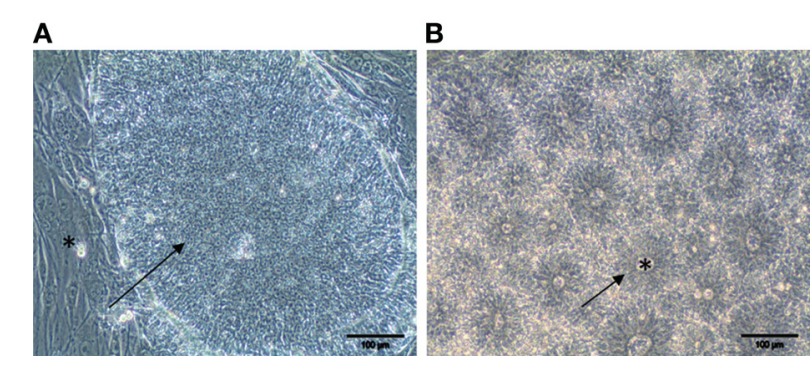

FIGURE 1 | Commitment of hPSC along the neural lineage. (A) Phase contrast morphology of a colony of undifferentiated pluripotent hESC (arrow) cultivated on a feeder layer of mouse fibroblast (star). (B) After eight days of treatment with the BMP antagonist Noggin and the Activin inhibitor SB431542, structures resembling the neural tube are clearly identifiable. Neuro-epithelial cells form an epithelium (arrow) surrounding a lumen (star) Scale bar: $100 \mu \mathrm{m}$

applied in vitro to promote full commitment of hPSC into neural progenitors.

The formation of early embryonic tissues is the result of a tightly controlled sequence of events in which the cellular environment, or niche, plays an instrumental role. Embryonic tissues secrete molecules that coax stem cells and progenitors toward a specific lineage. In the nervous system, the earliest NPC is found in the neuroectoderm, arising from the central part of the primitive ectoderm after the appearance during gastrulation of the notochord, one of organizer mesodermal structures (Harland, 2000). Noggin, an antagonist of the bone morphogenetic protein (BMP) receptors, was one of the first identified instructive proteins that play a crucial role during the formation of the neuroectoderm. Noggin is secreted by notochord cells. By blocking BMP-dependent pathways, Noggin instructs surrounding ectodermic cells to adopt a more specialized neural fate, ending up in the formation of the neural plate (Smith and Harland, 1992; Lamb et al., 1993; Zimmerman et al., 1996). However, it recently emerged that inhibition of BMP-dependent pathways by their endogenous inhibitors Noggin, Follistatin, or Chordin, is not sufficient to completely induce neuralization in vertebrates. BMP molecules exert their neural-suppressing activity by activating the kinase domain of their specific receptors and inducing the phosphorylation of two receptor-associated proteins Smad5 and Smad1. Once activated, Smad5/1 propagates the signaling cascade by binding to the co-factor Smad4 and translocating to the nucleus to exert a pro-transcriptional activity. This might indicate that wider blockage of pathways that activate the transcription factors of the Smad family is required to fully control the neural induction process.

In agreement, complete neuralization is obtained with dual inhibition of BMP pathways, which act through the Smad1/5dependent cascade, and of the activin/nodal pathway, which signals through Smad2/3 as receptor-linked proteins (Bell et al., 2003; Linker and Stern, 2004; Chang and Harland, 2007). In 2009, Chambers and collaborators used a combination of BMP and the Smad-dependent transforming growth factor $\beta$ (TGF $\beta$ ) pathways to fully achieve neural conversion of human embryonic and iPSC lines into Pax6-positive cells. When used to destabilize 
TGF/activin- and Nanog-mediated pluripotency networks, the TGF $\beta$ receptor inhibitor SB431542 suppresses mesendodermal fates by inhibiting endogenous activin and nodal signals. Neural conversion of the resulting ectodermal cells was achieved with addition of the BMP inhibitor Noggin. The obtained neuroepithelial cells were competent to form neural rosettes and could further be differentiated into mesencephalic dopaminergic neurons and spinal motoneurons (Chambers et al., 2009). This approach is fully amenable to clinical grade production since it avoids serum and cells of animal origin.

\section{REGIONAL PATTERNING OF PSC-DERIVED NEURO-EPITHELIAL CELLS}

In addition to the acquisition of an early neural fate, cells aimed at therapeutic purposes must be differentiated into restricted, neural or glial, progenitors. Failure to do so results in formation of adverse structures after transplantation (see below).

During neurogenesis, the potential of each cell to adopt a specific phenotype differs according to its position along the rostro-caudal and dorso-ventral (DV) axis. Early region-specific molecular programming is essential to the existence of divergent structures in the brain. In mammal embryos, the anterioposterior (AP) axis is specified as gastrulation and neurulation proceed. The closing neural tube quickly divides into three primary vesicles: the anterior forebrain, the midbrain, and the posterior hindbrain. The forebrain will further sub-divide into two structures, the rostral telencephalon and the diencephalon (Pombero and Martinez, 2009), whereas the caudal hindbrain will form the rhombencephalon and the spinal cord. Secondary patterning sequences will further specify DV domains inside each structure (Lupo et al., 2006). The organization of these secondary vesicles prefigures the future brain structures. The telencephalon will give rise to the cortex in its dorsal part and to anterior basal ganglia including the caudate and the putamen in its ventral part. The thalamus and hypothalamus will emerge from the ventral diencephalon, the substantia nigra (SN) from the ventral mesencephalon, the cerebellum from the dorsal domain of the rhombencephalon, and spinal motor neurons will form from the ventral part of the spinal cord. The potential of a given population of progenitors to produce specific neurons is tightly dependent on the position of these progenitor cells along the AP and DV axes of the developing nervous system. Here again, extra-cellular signals provide a group of neural progenitors with the unique competency to produce specific neuronal or glial subtypes. The activity of these signals are spatiotemporally integrated by neural progenitors to determine the specific combinations of transcription factors activated in distinct AP and DV compartments of the CNS (Vieira et al., 2010). Elucidation of the molecular basis of regional patterning is a sine qua non condition to efficiently commit hPSCderived naïve neuro-epithelial cells to produce the desired type of end-product.

The most potent factor for induction of a caudal neural tube fate is retinoic acid, a lipophilic molecule derived from vitamin A (Durston etal., 1989; Papalopulu etal., 1991; Blumberg et al., 1997). Retinaldehyde dehydrogenases (Raldh), the enzymes that control RA synthesis, are activated in somites, leading to a gradual release of RA along the posterior part of the neural tube (Molotkova et al., 2005). RA passively diffuses across the target cell plasma membrane and binds to its nuclear receptors RARs. Binding leads to the activation of retinoic acid responsive element (RARE)-dependent genes. In the posterior neural tube, RA activates the caudal genetic program that relies on Hox homeodomain genes, leading to the formation and further regionalization of the hindbrain and the spinal cord. Other caudalizing factors include members of the fibroblast growth factor (FGF) family and Wnts. However, these molecules have milder effects that mainly rely on the intrinsic ability of the neural cells to respond to these factors, a process that may itself be controlled by RA (Ogura and Evans, 1995; Bel-Vialar et al., 2002). The most anterior part of the neural tube is considered to adopt a rostral fate by default (Rallu et al., 2002). However, this anterior fate can be promoted by exposition of early neuro-epithelial cells to inhibitors of the BMPs, Noggin and Chordin, and by inhibitors of the Nodal pathway, Cripto and Cerberus (Lamb et al., 1993; Hemmati-Brivanlou et al., 1994; Bouwmeester et al., 1996; Bachiller et al., 2000; Liguori et al., 2009), indicating some degree of specificity for these factors.

DV patterning of the neural tube mainly results from a balance between the antagonized actions of members of the sonic hedgehog $(\mathrm{SHH})$ family. $\mathrm{SHH}$ family members were first isolated in the early 1990s and act as bona fide morphogenetic signals to determine the ventral progenitor identity (Lee et al., 1992; Echelard et al., 1993; Tashiro et al., 1993). Cleavage of SHH releases two secreted proteins that correspond to the $19 \mathrm{kDa}$-terminal and the $25 \mathrm{kDa}$ C-terminal domains. The $\mathrm{N}$-terminal of $\mathrm{SHH}$ mediates all signaling activities in vertebrates and invertebrates (for review see Hammerschmidt et al., 1997). SHH N-terminus domain binds its transmembrane receptor Patched at the cell surface of competent cells, thus releasing the constitutive inhibition of the adjacent trans-membrane factor Smoothened (Smo). Within the nucleus of the responding cell, zinc-finger transcription factors of the Gli family act at the last step of the SHH signal transduction pathway (Hynes et al., 1997; Ruiz i Altaba, 1998). The region specific combinatory effect of Gli2 activation and Gli3 repression by $\mathrm{SHH}$ in different areas of the neural tube determines the regional result on neural patterning (Zervas et al., 2004; Blaess et al., 2006). During the nervous system development, SHH molecules are secreted in the ventral part of the embryo by cells located inside the neural floor plate and by the surrounding notochord. A gradient of $\mathrm{SHH}$ along the DV axis will be transduced into a gradient of intracellular Gli activity, which can account for the morphogen activity of $\mathrm{SHH}$ by inducing the combinatorial expression of the transcription factors that ultimately defines the identity of the neural progenitor cell (Stamataki et al., 2005). Dorsally, SHH activities are counteracted by BMPs and Wnts. BMPs are required for the correct specification of dorsal cell types and may act by both desensitizing target cells to SHH signal and sustaining the activity of the SHH-repressed Gli-3. In addition, the Wnt canonical pathway also restricts $\mathrm{SHH}$ signaling via a direct effect on Gli-3 and by inducing BMP expression.

\section{LOCAL PATTERNING: THE FINAL SPECIFICATION}

A number of developmental molecules have been successfully applied on PSC-derived neuro-epithelial cells to produce a variety of neuronal progenitor populations and, subsequently, neuronal types relevant for cell replacement strategies. From 
progenitor pools of the forebrain, the main neurons of interest are glutamatergic cortical projection neurons, GABAergic interneurons and projection neurons, and cholinergic neurons. Oligodendrocytes add a non-neuronal, although neural, population.

\section{Telencephalic populations}

Glutamatergic projection neurons of the neo-cortex result from the terminal differentiation of progenitors located in the pallium, or immature cortex progenitors, on the dorsal part of the telencephalon. As described above, anterior fates have been obtained from PSC using default protocols in the absence of any morphogens (Li et al., 2009; Zeng et al., 2010). The resulting population of neural progenitors express high levels of the anterior marker FoxG1 and can be further patterned dorsally or ventrally using the interplay between Wnt and SHH pathways. Further differentiation of primitive neuroepithelial cells in the absence of SHH spontaneously produce neural progenitors that express the dorsal markers Pax6 and Emx1 but do not express the ventral markers Gsh-2 and Nkx2.1. In hPSC, this spontaneous dorsal fate can be actively promoted by high levels of endogeneous Wnt molecules that are produced by human cells during the first weeks of differentiation. When terminally differentiated in vitro, these progenitor cells ultimately generate early Tbr 1 and Ctip2 positive cortical neurons (Li et al., 2009; Zeng et al., 2010). This default dorsal fate can be challenged by exposition of the neuro-epithelial cells to $\mathrm{SHH}$ and by inhibiting the Wnt pathway in order to obtain forebrain ventral progenitors. Major types of neurons are generated from ventral forebrain progenitors located in the ganglionic eminence. GABAergic medium spiny neurons of the striatum, and cholinergic neurons of the basal forebrain, originate from the lateral (LGE) and medial ganglionic eminence (MGE), respectively. The main GABAergic interneurons originate from both (Olsson et al., 1998; Letinic et al., 2002). Treatment of neuro-epithelial rosettes with $\mathrm{SHH}$ and the inhibitor of the Wnt pathway Dickkopf 1 (DKK1) almost completely converts the Pax6-expressing dorsal precursors into ventral progenitors that express Gsx2 and Nkx2.1 (Aubry et al., 2008; Li et al., 2009).

Fine-tuning of $\mathrm{SHH}$ and Wnt gradients can further discriminate LGE or MGE progenitor fates from hPSC. In the presence of low concentrations of $\mathrm{SHH}$, the obtained progenitors exhibit the phenotype of LGE cells, with expression of Gsx2 and low levels of Pax6, but no expression of the more ventral marker Nkx2.1. Upon SHH removal, these LGE-like progenitors differentiate into GABAergic neurons that display glutamic acid decarboxylase, the dopaminergic receptor- 1 second messenger DARPP32, and the striatal marker Meis2 (Aubry et al., 2008). In contrast, in the presence of high concentrations of $\mathrm{SHH}$, the dorsal transcription factors, Pax6, and Emx1, are completely repressed, and the ventral transcription factor Nkx2.1 is upregulated. Using these conditions, one can generate a progenitor population enriched in the MGE phenotype with repression of the LGE markers Meis2 and Gsx2 and homogeneous expression of Nkx2.1. MGE-like progenitors give rise in vitro to GABAergic interneurons and projection cholinergic neurons that express the choline acetyltransferase (ChAT) enzyme and the vesicular acetylcholine transporter VAchT (Liu and Zhang, 2010).

\section{Mesencephalic populations}

The midbrain dopaminergic (mDA) neuron has been a prime target in stem cell research and developmental neurobiology, owing to its role in Parkinson's disease. DA neurons responsible for movement control are mainly located in the SN and the ventral tegmental area (VTA) in the midbrain. DA neurons derive from progenitors located in the floor plate of the ventral part of the embryonic midbrain (Ono et al., 2007). Accordingly, most protocols that aim at deriving DA neurons progenitors from hPSC rely on the exposition of early neuro-epithelial to $\mathrm{SHH}$ and to FGF-8, a weak but sufficient caudalizing factor (Perrier et al., 2004; Andersson et al., 2006; Friling et al., 2009; Rhee et al., 2011; Swistowski et al., 2011). Recently, the small molecule CHIR99021, a glycogen synthase kinase (GSK)-3 inhibitor, has been identified as a more potent caudalizing agent that FGF-8, and has been used to produce high yields of $\mathrm{mDA}$ in combination with a modified form of SHH. The early ventral midbrain specification firstly characterizes by the activation of the midbrain marker En-1 and the floor plate marker FoxA2, and the absence of the forebrain marker FoxG1 (Fasano et al., 2010; Kriks et al., 2011). Upon progression through a more restricted DA fate, these progenitors express the typical transcription factors Nurr-1 and Pitx-3, as observed during mammalian development. In agreement, Nurr-1 and Pitx3 cooperatively promote terminal differentiation of human and murine ESC into DA neurons (Martinat et al., 2006). In the presence of the pro-survival factor brain derived neurotrophic factor (BDNF), DA neuron progenitors produce tyrosine hydroxylase-positive but dopamine $\beta$-hydroxylase-negative neurons, indicating their potential to synthesize monoamines but not norepinephrine, hence DA. After transplantation, these DA neurons could correct neurological deficit in two different animal models of Parkinson's disease, which fully validates their functionality (Kriks et al., 2011; Rhee et al., 2011).

Serotonin has important functions in the etiology and treatment of a number of psychiatric diseases (Hedlund, 2009). Like DA neurons, serotonergic neurons are located around the boundary between the midbrain and hindbrain and might be regulated by similar developmental signals, including $\mathrm{SHH}$ (Ye et al., 1998). Adding $\mathrm{SHH}$ in the last stages of differentiation of ESC dramatically increases the yield of serotonergic neurons (Lee et al., 2000).

\section{Spinal cord motoneurons}

The progenitors of the spinal cord motor neurons represent another attractive source of cells relevant for replacement therapy. Spinal cord motor neurons originate from the motoneuron progenitor domain located in the ventral developing spinal cord (Soula et al., 2001). In order to obtain efficient spinal motor neurons in vitro, primitive neuro-epithelial cells need to be caudalized as the neural induction proceeds, using high concentrations of RA. The expression of genes from the Hox family, particularly Hoxb4, Hoxb9, Hoxc5, and Hoxc8, sign the posterior fate of the resulting progenitor. In parallel, ventralization of the caudal neuroepithelium with $\mathrm{SHH}$ limits the cells to a ventral spinal fate, including Olig2-expressing motor neuron progenitors. After several weeks of patterning, factor withdrawal generates 
HB9-expressing post-mitotic motor neurons that express the full pattern of motor neuron transcription factors, including Lhx3 and Isl (Soundararajan et al., 2006; Li et al., 2008). Further culture of these neurons with the growth factors GDNF, BDNF and NT3 , leads to their partial maturation characterized by expression of the specific enzymes ChAT and VAChT that are responsible for the synthesis of acetylcholine and primary function of motor neurons at the nerve-muscle interface. Co-culture of human motor neurons with a primary culture of myocytes induces clustering of acetylcholine receptors on myotubes, as revealed by bungarotoxin staining, suggesting that these motor neurons are functional and able to innervate their natural target organ. Transplantation of human ESCs-derived motor neurons into chick embryonic spinal cord and mouse spinal cord showed survival of grafted neurons and phenotypic features of spinal cord motor neurons (Lee et al., 2007). However, the functionality of hESC-derived motor neurons in vivo has not yet been fully demonstrated. Derived in ESC, these differentiation protocols have been successfully transferred to iPSC (Karumbayaram et al., 2009). SHH has also been replaced by purmorphamine, a small molecule agonist with the ability to bind Smo. This modification improves the efficacy of the protocol and produces over 50\% HB9-expressing motor neurons. It also bypasses the use of recombinant proteins, thus facilitating the translation of the protocol to industrial and clinical applications (Li et al., 2008).

\section{Oligodendrocytes}

Demyelination is a key component in the pathogenesis of many neurologicaldisordersincluding multiplesclerosis, traumaticbrain and spinal cord injuries, and Alzheimer's disease (Lassmann, 2009). Transplantation of myelinating cells may offer a therapeutic approach to restore neurological function in these diseases by both blocking secondary axonal degeneration and restoring axonal transmission (Erceg et al., 2010; Nori et al., 2011; Yasuda et al., 2011). Oligodendrocytes represent the myelinating cells of the CNS. Oligodendrocyte precursor cells (OPCs) are generated during embryogenesis from the ventral part of the CNS and, in the adult CNS, in response to brain or spinal cord injuries (Zhang et al., 1999). In the telencephalon, OPC are generated in the MGE and migrate laterally and dorsally to colonize other telencephalic areas, including the neocortex (Vallstedt et al., 2005; Battiste et al., 2007). In the diencephalon, OPC formed in the ventral part migrate secondarily to their target sites, including the thalamus and the cerebellum (Kessaris et al., 2006). Spinal OPC mainly derive from neural progenitors located in the same territories than $\mathrm{MN}$ in the ventral part of the developing spinal cord. The major inductive morphogenetic signal for the appearance of OPCs in the ventral region of the spinal cord and the telencephalon is $\mathrm{SHH}$ (Nicolay et al., 2007). However, analysis of oligodendrogenesis in Shh-/knock-out mice has shown that OPCs are also generated in the spinal cord and forebrain in a SHH-independent manner, although dependent on FGF2 (Kessaris et al., 2004; Cai et al., 2005). In addition to FGF2, blockage of BMP-dependent signaling pathways may be involved. BMP antagonizes $\mathrm{SHH}$-induced oligodendrocyte specification, and inhibition ofBMP signaling is sufficient to induce OPC formation both in vivo and in vitro (Lachapelle et al., 2002; Vallstedt et al., 2005).
Alternative pathways may be responsible for OPC production in the injured adult CNS. Intraperitoneal injection of FGF2 but also platelet-derived growth factor $\mathrm{AB}$ (PDGFAB) has been shown to promote the differentiation of adult NSC into OPC (Lachapelle et al., 2002). In vivo, insulin-like growth factor 1 (IGF1) produced by local astrocytes and microglia in response to demyelination can instruct adult neural progenitor cells in thehippocampus to become oligodendrocytes by upregulating antagonists of BMP (Hsieh et al., 2004). A large number of studies have demonstrated that mouse ESC can be directed to an OPC fate and further differentiated as myelinating oligodendrocytes. Propagation of PSC-derived neural precursors in medium containing either FGF2/EGF or FGF2/PDGF yields homogenous populations of glial progenitors capable of forming oligodendrocytes (Billon et al., 2002). Alternatively, oligodendrocytes can be derived by RA-induced ES cell differentiation (Liu et al., 2000). Both methods induce the formation of OPC and oligodendrocytes that survive and engraft upon transplantation into the demyelinated immature and adult CNS where they myelinate axons. Several protocols using timely exposure of NSC to factors including SHH, EGF, FGF2, and Noggin has been successfully developed to produce large amount of functional oligodendrocytes from human PSCs (Glaser et al., 2005; Nistor et al., 2005; Kang et al., 2007; Hu et al., 2009; Sundberg et al., 2011).

\section{TURNING A CELL CULTURE INTO A THERAPEUTIC PRODUCT}

Restorative approaches after brain lesion intuitively require from therapeutic products to reflect the diversity and specificity of missing cell populations. In practice, efforts are usually driven toward the main population affected by the disease, i.e., GABAergic and glutamatergic neurons for cortical lesions, GABAergic medium spiny neurons for striatal lesions (stroke and Huntington's disease), DA neurons for Parkinson's disease, motoneurons for spinal lesions, and ALS and oligodendrocytes for demyelinating diseases. Major issues in using neural progenitors for intracerebral transplantation are, firstly, the selection of robust differentiation protocols to produce safe grafts and, secondly, maintenance of the pre-transplantation commitment in the diseased environment. Finally, the degree of integration of grafted cells is of relevance to restore impaired circuits.

\section{REQUIREMENT ONE: SAFETY}

A main concern for cell replacement therapy with PSC is total eviction of the risk to generate adverse structures in the recipient brain. Adverse structures materialize in two forms, teratoma and masses of hyperproliferative NSC called "overgrowths" (Wernig et al., 2004; Mitjavila-Garcia et al., 2005; Brederlau et al., 2006; Roy et al., 2006; Aubry et al., 2008). Non-malignant teratoma are defined by the presence of tissue derivatives from at least two different germ layers and are generated through high, although transient, proliferation of undifferentiated cells. A systematic analysis of the fate of grafted cells according to their in vitro, pretransplantation, maturation stage revealed that teratoma form only with cultures at the early neuroepithelial stage. These cultures are highly heterogeneous and contain cells with detectable levels of pluripotency genes (Seminatore et al., 2010). Limited differentiation after embryoid bodies or rosette formation might 
also lead to formation of cystic cavities that indicate an ectodermal fate (Aubry et al., 2008; Seminatore et al., 2010). Strategies developed to eliminate the risk of teratoma include sorting of neural progenitors to exclude insufficiently differentiated cells (Chung et al., 2006; Fukuda et al., 2006), dilution of transplanted cells (Björklund et al., 2002; Inden et al., 2004), transformation of cells to express suicide genes (Aebischer et al., 1996) or, more simply, improvement of differentiation protocols (Kim et al., 2002; Tabar et al., 2005; Brederlau et al., 2006; Bühnemann et al., 2006; Dihné et al., 2006; Guillaume et al., 2006; Daadi et al., 2008; Seminatore et al., 2010). The latter is obviously the most reliable for accurate up-scaling of progenitors production.

Teratoma formation might also depend on the graft $v s$. host immunological distance. Transplantation in a mouse-to-rat xenograft situation seemed to lessen ESC pluripotency and ability to form tumors in comparison to a mouse-to-mouse situation (Erdö et al., 2003). This poses a major safety problem for allogenic transplantation in humans. However, studies in cynomolgous monkeys with allogenic transplantation of ESC-derived NPC revealed no adverse structures and a clear functional benefit (Muramatsu et al., 2009). Further studies in large animals would be needed to clarify this point.

Overgrowth corresponds to the hyperproliferation of neural cells after transplantation. Overgrowths are observed after grafting early NSC, close to the rosette stage, that keep in vivo the high proliferative capacity that characterizes them in vitro (Roy et al., 2006; Aubry et al., 2008). Although the resulting cell types are exclusively neural, graft overgrowth might compress and destroy surrounding host tissue. Like teratoma, overgrowths are eliminated by extended differentiation over the last hyperproliferative wave in vitro, that is also observed during development (Zhang et al., 2001; Seminatore et al., 2010).

Cell masses that can be assimilated to overgrowth of non-neural cells have been reported after intracerebroventricular infusion of autologous bone marrow-derived SC (BMSC) in severe experimental autoimmune encephalomyelitis (EAE), a model of multiple sclerosis (Grigoriadis et al., 2011). Masses were not observed in similar experimental conditions either in animals with mild EAE (Grigoriadis et al., 2011), suggesting a role of the inflammatory status of recipient animals, nor after infusion of neonatal NPC, suggesting a cell-specific effect. This effect was not observed by others (Siatskas et al., 2010; Harris et al., 2012) in similar models. However, collagen deposition and axonal injury were reported after administration of BMSC in a model of spinal lesion (Hunt et al., 2008). Thus far, no major adverse effects were reported in pilot treatments of multiple sclerosis and ALS patients with intrathecal or intravenous delivery of autologous BMSC (Mohyeddin et al., 2007; Karussis et al., 2010; Yamout et al., 2010).

\section{REOUIREMENT 2: KEEPING THE IN VITRO COMMITMENT AFTER TRANSPLANTATION}

After transplantation, cells have to face the heterogeneous environment of the lesioned or diseased brain. Cells withdrawn from totally defined and constant culture conditions must compose after transplantation with a complex milieu, highly unstable and rich in factors susceptible to modulate their fate. Grafted cells will also have to face cellular and molecular components of the host immune system that will tend to eliminate them.

\section{Lessons from adult neurogenesis and the niche concept}

The most striking example of successful survival and differentiation of NSC in the brain is adult neurogenesis. Neurogenesis in the adult brain occurs mainly in two discrete areas, the walls of the lateral ventricle and the dentate gyrus of the hippocampal formation (Altman, 1962; Sierra et al., 2011). Areas of adult neurogenesis contain all instructive cues for life-long maintenance of this precious pool of cells, and are therefore called "niche." In pathological conditions, neural SC responds to modifications of cerebral homeostasis by modifying their proliferation and migration patterns (Moyse et al., 2008). In the SVZ, the particular location of NSC (the type B cells), with processes apposed to both the cerebrospinal fluid and blood vessels, makes them particularly sensitive to changes triggered at distant sites. As in rodent, NSC in the human SVZ niche live in close proximity with blood vessels and the ependyma (Quinones-Hinojosa and Chaichana, 2007). As a result, molecular cues derived from blood, cerebrospinal fluid, endothelial and glial cells, and axonal afferents that terminate into the niche can modulate the behavior of neurogenic neuroblasts (Moyse et al., 2008; Tavazoie et al., 2008) and, likely, of transplanted progenitors (Onteniente and Polentes, 2011). Ependymal cells release noggin, an inhibitor of the BMP pathway that regulates the proliferation and differentiation of adult SVZ NSC (Kokovay et al., 2008; Zhao et al., 2008). Noggin is used in vitro to promote the differentiation of pluripotent SC into early neural progenitors (Itsykson et al., 2005; Sonntag et al., 2007). Enhancing the supportive niche function after transplantation might have a positive impact on transplant survival and influence fate decisions of transplanted progenitors. Growth factors, neurotransmitters and $\mathrm{SHH}$ are other secreted proteins that regulate proliferation and differentiation of NSC in vitro and enhance neurogenesis in both hippocampus and SVZ (Moyse et al., 2008). Interestingly, after transplantation into the medial part of the striatum, NPC were found into the adjacent SVZ, where they adopted the fate and destination of SVZ-derived migrating neuronal precursors (Tabar et al., 2005). Preferential homing to the SVZ was also reported by Hoehn and collaborators after transplantation of neural cells into the striatum (Hoehn et al., 2002). This suggests that the niche formed by areas of adult neurogenesis is attractive to exogenous neuronal precursors and is able to influence their fate to produce neurons with characteristics close to the endogenous ones. In contrast, repeated demonstration of the presence of a variety of neuronal types in intrastriatal grafts from NPC, including GABAergic (Seminatore et al., 2010) and dopaminergic (Kriks et al., 2011) neurons, show that the influence of the neurogenic niche is limited or, at the least, that the degree of modulation varies according to the extent of lineage restriction before grafting. Here again, the pre-transplantation degree of differentiation and homogeneity of transplanted populations are instrumental.

\section{Lessons from experimental studies}

The exact composition of the external milieu after brain lesion or during neurodegenerative diseases is far from being known, 
although some insights were provided by large-scale genomic data (Sharp et al., 2011). Pleiotropic factors like FGF2, EGF, or IGF1, which are released during brain insults, are known to regulate NSC proliferation to an ill-defined extent. Most trophic factor-triggered signal transduction pathways share a common denominator, the serine-threonin kinase Protein Kinase B, also named Akt (Brazil and Hemmings, 2001). Besides its canonical role in cell survival, Akt is expressed in neural progenitors (Owada et al., 1997) and is involved in NSC proliferation through regulation of p21 (Rossig et al., 2001) and mTOR (Navé et al., 1999). In vivo overexpression of Akt enhances proliferation of NSC through a p21-independent, mTOR-dependent, pathway (Sinor and Lillien, 2004). According to these observations, the presence of FGF2 or EGF in the environment of transplanted cells might favor a NSC state, with associated dangers of phenotypic regression and generation of a highly proliferative graft. In addition, the effects of FGF family members on neural differentiation from embryonic NPCs depend on the concentration of the factor. Low concentrations have been reported to improve cell survival, while higher concentrations promote proliferation (Ray et al., 1997; Kelly et al., 2003). The resulting effects on transplanted cells can hardly be predicted on the basis of these data, and most of our knowledge come from empirical testing in transplantation paradigms.

An example of the role of environmental signals has been recently provided by Joannides and collaborators (Joannides et al., 2007). ESC-derived NSC were grafted into the neonatal rat brain, the uninjured adult rat brain, and the adult rat spinal cord with gliotoxic demyelination. Authors observed that maturation of NSC was delayed after engraftment into the uninjured neonatal brain, in comparison with the maturation kinetics of the cells in vitro. Grafting into the striatum after excitotoxic lesion accelerated maturation, although no terminally differentiated GABAergic medium spiny neurons were observed. Grafting into the demyelinated spinal cord resulted in exclusive astroglial differentiation. No neurons or oligodendrocytes were observed, contrasting with the predominant neuronal differentiation observed in vitro. These results show that the micro-environment does influence both lineage commitment and temporal maturation of grafted NSC. However, this influence does not include the last maturation stages of grafted cells and, most unfortunately, does not promote the requested phenotypes. Similar results were obtained after grafting NSC from hESC into the striatum of 6-hydroxydopamine-treated rats, with a reduced tendency to produce DA neurons compared to their behavior in vitro (Ben-Hur et al., 2004), and in a focal demyelination paradigm (Tabar et al., 2005). Here, NPC grafted into the non-lesioned brain displayed extensive migration into the host parenchyma and differentiated into neural cell types, including oligodendrocytes. Transplantation into a demyelinating lesion did not change the overall differentiation profile of grafted cells. Myelinating oligodendrocytes were found in the presence or absence of demyelinating insult, showing that the environment had little effect on neural precursors. Contrasting results were reported using immature neuro-epithelial cells, characterized by expression of Sox1, Pax6, and Ki67, grafted into the neonatal mouse brain (Guillaume et al., 2006).
The discrepancies observed in these studies very likely come from the differentiation protocol and maturation stage of cells at the time of transplantation, two critical parameters that should be carefully compared. A longitudinal study of the resulting commitment of hESC-derived neural progenies according to their pretransplantation maturation stage revealed that the influence of the post-ischemic environment is strictly dependent on the developmental stage at the time of transplantation (Seminatore et al., 2010). Early NPC grafts, which still contain neuro-epithelial cells, produced more cystic cavities, which indicates epithelial fate, after transplantation into a severe ischemic lesion than into a mild one, suggesting a de-differentiation potential of the environment. This sensitivity was lost in more differentiated NPC, which produced GABAergic homotopic neurons independently of the severity of the lesion. Further confirmation of the importance of differentiation before transplantation comes from a comparison of the fate of early neuro-epithelial cells from fetal hippocampus after transplantation into the fetal cortex, and into the lesioned or unlesioned adult cortex (Sheen et al., 1999). Cortical neurons were observed only after in utero transplantation. Transplantation into the adult environment resulted in production of glial cells and a notable absence of neurons. A clear relationship was observed in this study between the absence of neurotrophin receptors on neuro-epithelial cells and the absence of competency to respond to surrounding cues. Altogether, these results show that the fate of NPC transplanted into the lesioned brain is, for a large part, independent of environmental molecular control, and has more to see with the intrinsic developmental stage of the cells at transplantation.

\section{REQUIREMENT 3: INTEGRATION INTO HOST STRUCTURES}

For long-term efficacy of grafted cells, it can be reasonably considered that cells have to go beyond survival and differentiation into accurate cell types, to rebuilt impaired circuits, unless they are used only for their ability to release a mediator. It has for long been considered that, on the one hand, the adult brain was not permissive to axonal growth from exogenous cells and, on the other hand, that transplanted neurons would not receive sufficient signals from the host brain to understand where to send their axons. Cumulative experimental evidence has challenged this dogma over the last three decades, showing rewiring and stimulation of brain adaptive plasticity following transplantation, in correlation with functional improvements.

\section{Lessons from experimental studies}

A large body of literature converges to show the efficacy of intracerebral transplantation at functional level. Reversal of motor, sensorimotor, and cognitive deficits has been reported in all models of neurological disorders. The structural support for these improvements is less clear. For instance, the possibility for grafted neural precursors to reestablish disrupted circuits in the adult brain has been a matter of controversy (Gonzalez et al., 1988; Isacson et al., 1988; Wictorin et al., 1989; Guitet et al., 1994; Sorensen et al., 1996). Strategies have even been devised to help new axons grow toward correct target sites, mainly through tissue engineering with biodegradable scaffolds. However, an increasing 


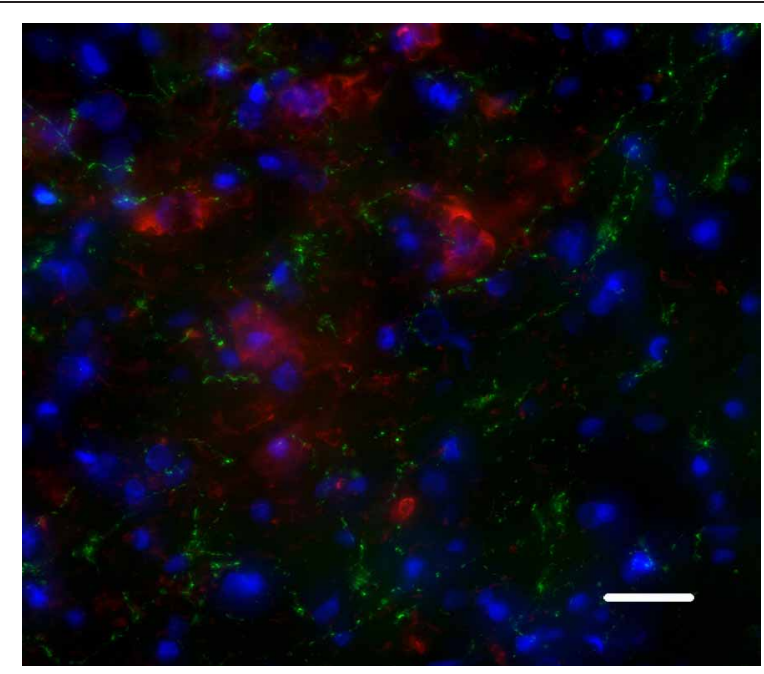

FIGURE 2 | Human neuronal precursors grafted into the post-ischemic striatum project onto the host substantia nigra, a normal target of medium spiny GABAergic neurons. Green: MTCO2, a maker of human fibers; Red: $\mathrm{TH}$, a marker of substantia nigra dopaminergic neurons. Scale bar: $20 \mu \mathrm{m}$.

number of studies converge to show that grafted neural progenitors are able to adopt correct phenotypes with regards to the missing populations, and to send axons toward deafferented targets. Gaillard et al. have revealed the possibility for cortical neurons from fetal mouse to restore a point-to-point connection with sensorimotor and motor targets in the recipient cortex, thalamus, and spinal cord, by growing axons that were properly myelinated by host oligodendrocytes (Gaillard et al., 2007). After grafting hiPSC-derived NPC in a stroke-induced striatal lesion, we observed a very specific sprouting of the GABAergic medium spiny neurons generated by the graft to the host $\mathrm{SN}$, suggesting reconstruction of the striato-nigral loop (Figure 2; Polentes et al., personal communication). These results suggest that, beyond the ability to grow axons over long distances, neural progenitors are actually able to recognize molecular cues present in the adult brain after an acute lesion. This has important implications for future application of SC therapy in ischemic or traumatic insults.

\section{Lessons from clinical studies}

A major result from clinical trials performed for patients with neurodegenerative diseases since the 1980 is that grafted neuroblasts and/or NSCs from human fetal tissue survive for years and restore local function in the grafted brain, indirectly suggesting integration and interaction with host brain structures (Lindvall and Björklund, 2011). The functionality of dopaminergic precursors grafted in Parkinson's patients has also been assessed by both dopamine release, ability to uptake the tracer $\left[{ }^{18} \mathrm{~F}\right]$ dopa and maintenance of post-synaptic D2 dopamine receptors (Piccini et al., 1999). Trials with PSC are quite recent, and no data are yet available on the behavior of intracerebrally grafted neural derivatives from PSC. The first trials with selected SC have been performed in stroke patients. In 2000, Kondziolka and collaborators reported the initial results of a pilot trial for 12 patients with basal ganglia stroke using the NTN2 neural cell line (Kondziolka et al., 2000). Autopsy on one patient 27 months after implantation confirmed that grafted cells had survived (Nelson et al., 2002). In six patients, increased positron emission tomography (Meltzer et al., 2001), correlated with improvement in the European Stroke Scale (Kondziolka et al., 2000), suggested functionality of the cells. Improvements in specific tests were also observed in a phase II randomized open-label trial with the same cell line (Kondziolka et al., 2005). Development of diffusion tensor imaging will be quite helpful in the future to define the extent of axonal sprouting and target innervation by grafted cells.

Although graft-host interactions can hardly be approached in grafted patients, noteworthy demonstrations of host-graft interactions have been recently provided from grafted Parkinson's and Huntington's disease patients. Both examples show that the reciprocal dialogue that establishes between grafted cells and their surrounding diseased tissue might have important consequences on both.

Parkinson's disease was the first neurological disorder to benefit from intracerebral transplantation. The possibility of propagation of the disease to transplanted cells was reported on deceased patients with 11-16 years post-transplantation delays. Hopefully in a very small proportion (1-4\%), grafted dopaminergic neurons contained a-synuclein-rich Lewy bodies and Lewy neurites characteristic of the disease. A number of mechanisms have been evoked to explain the transmission of clinical characteristics to unaffected exogenous cells, including inflammation, oxidative stress, excitotoxicity, reduced levels of trophic factor and a protein-mediated mechanism (Brundin et al., 2008). This observation has, so far, remained isolated.

Huntington's disease clinical trials with transplantation are more limited (Nicoleau et al., 2011). Autopsy results from three patients have been published (Cicchetti et al., 2009) that revealed surviving grafts 10 years after transplantation. In two patients, grafts had formed striatal-like tissue and contained neurons with markers of mature striatal projection neurons and interneurons, none of which contained the Huntingtin aggregates typical of the disease. However, in a phase II multicentric-center study, grafting was found to elicit an alloimmmunisation reaction from the recipient in half of the patients (Krystkowiak et al., 2007). Alloimmunisation is an immune reaction of the host to antigens expressed by an individual of the same species that might progressively lead to graft rejection. Although this is not directly a response of grafted cells to environmental cues, it shows the capacity of grafted cells to elicit a dramatic response in their host.

\section{CONCLUSION}

PSCs hold the potential to revolutionize the field of neuroregenerative medicine by offering a robust and flexible source of allogenic or HLA-compatible neural precursors. Key achievements have been performed regarding our ability to control neuronal fate in vitro and the capacity of hPSC-derived neural progenitors to engraft into a host brain has been demonstrated 
up to the level of circuit reconstruction. However, many challenges remain to be dealt with to fully validate the use of hPSC as a routine source of cells for replacement strategies. In particular, the relationships between the observed functional effects and the degree of integration of grafted cells into the host

\section{REFERENCES}

Aebischer, P., Schluep, M., Déglon, N., Joseph, J. M., Hirt, L., Heyd, B., Goddard, M., Hammang, J. P., Zurn, A. D., Kato, A. C., Regli, F., and Baetge, E. E. (1996). Intrathecal delivery of CNTF using encapsulated genetically modified xenogeneic cells in amyotrophic lateral sclerosis patients. Nat. Med. 2, 696-699.

Altman, J. (1962). Are new neurons formed in the brains of adult mammals? Science 135, 1127-1128.

Andersson, E., Tryggvason, U., Deng, Q., Friling, S., Alekseenko, Z., Robert, B., Perlmann, T., and Ericson, J. (2006). Identification of intrinsic determinants of midbrain dopamine neurons. Cell 124, 393-405.

Aubry, L., Bugi, A., Lefort, N., Rousseau, F., Peschanski, M., and Perrier, A. L. (2008). Striatal progenitors derived from human ES cells mature into DARPP32 neurons in vitro and in quinolinic acid-lesioned rats. Proc. Natl. Acad. Sci. U.S.A. 105, 16707-16712.

Bachiller, D., Klingensmith, J., Kemp, C., Belo, J. A., Anderson, R. M., May, S. R., Mcmahon, J. A., Mcmahon, A. P., Harland, R. M., Rossant, J., and De Robertis, E. M. (2000). The organizer factors Chordin and Noggin are required for mouse forebrain development. Nature 403, 658-661.

Battiste, J., Helms, A. W., Kim, E. J., Savage, T. K., Lagace, D. C., Mandyam, C. D., Eisch, A. J., Miyoshi, G., and Johnson, J. E. (2007). Ascll defines sequentially generated lineage-restricted neuronal and oligodendrocyte precursor cells in the spinal cord. Development 134, 285-293.

Bel-Vialar, S., Itasaki, N., and Krumlauf, R. (2002). Initiating Hox gene expression: in the early chick neural tube differential sensitivity to FGF and RA signaling subdivides the HoxB genes in two distinct groups. Development 129, 5103-5115.

Bell, E., Munoz-Sanjuan, I., Altmann, C. R., Vonica, A., and Brivanlou, A. H. (2003). Cell fate specification and competence by Coco, a maternal BMP, TGFbeta and Wnt inhibitor. Development 130, 1381-1389.
Ben-Hur, T., Idelson, M., Khaner, H., Pera, M., Reinhartz, E., Itzik, A., and Reubinoff, B. E. (2004). onic stem cell-derived neural progenitors improves behavioral deficit in Parkinsonian rats. Stem Cells 22, 1246-1255.

Billon, N., Jolicoeur, C., Ying, Q. L., Smith, A., and Raff, M. (2002). Normal timing of oligodendrocyte development from genetically engineered, lineage-selectable mouse ES cells. J. Cell Sci. 115, 3657-3665.

Björklund, L. M., Sánchez-Pernaute, R., Chung, S., Andersson, T., Chen, I. Y., McNaught, K. S., Brownell, A. L., Jenkins, B. G., Wahlestedt, C., Kim, K. S., and Isacson, O. (2002). Embryonic stem cells develop into functional dopaminergic neurons after transplantation in a Parkinson rat model. Proc. Natl. Acad. Sci. U.S.A. 99, 2344-2349.

Blaess, S., Corrales, J. D., and Joyner, A. L. (2006). Sonic hedgehog regulates Gli activator and repressor functions with spatial and temporal precision in the mid/hindbrain region. Development 133, 1799-1809.

Blumberg, B., Bolado, J. Jr., Moreno, T. A., Kintner, C., Evans, R. M., and Papalopulu, N. (1997). An essential role for retinoid signaling in anteroposterior neural patterning. Development 124, 373-379.

Bouwmeester, T., Kim, S., Sasai, Y., Lu, B., and De Robertis, E. M. (1996). Cerberus is a head-inducing secreted factor expressed in the anterior endoderm of Spemann's organizer. Nature 382, 595-601.

Brazil, D. P., and Hemmings, B. A. (2001). Ten years of protein kinase B signalling: a hard Akt to follow. Trends Biochem. Sci. 26, 657-664.

Brederlau, A., Correia, A. S., Anisimov, S. V., Elmi, M., Paul, G., Roybon, L., Morizane, A., Bergquist, F., Riebe, I., Nannmark, U., Carta, M., Hanse, E., Takahashi, J., Sasai, Y., Funa, K., Brundin, P., Eriksson, P. S., and Li, J. Y. (2006). Transplantation of human embryonic stem cell-derived cells to a rat model of Parkinson's disease: effect of in vitro differentiation on graft survival and teratoma formation. Stem Cells 24, 1433-1440.

Brundin, P., Li, J. Y., Holton, J. L., Lindvall, O., and Revesz, T. (2008). Transplantation of human embry-

circuitry deserve full characterization. The development of imaging techniques, in particular of diffusion tensor imaging, should allow fiber tracking and a better characterization of the extent of rewiring and fiber development after grafting into the human brain.

Research in motion: the enigma of Parkinson's disease pathology spread. Nat. Rev. Neurosci. 9, 741-745.

Bühnemann, C., Scholz, A. Bernreuther, C., Malik, C. Y., Braun, H., Schachner, M., Reymann, K. G., and Dihné, M. (2006). Neuronal differentiation of transplanted embryonic stem cell-derived precursors in stroke lesions of adult rats. Brain 129, 3238-3248.

Cai, J., Qi, Y., Hu, X., Tan, M., Liu, Z., Zhang, J., Li, Q., Sander, M., and Qiu, M. (2005). Generation of oligodendrocyte precursor cells from mouse dorsal spinal cord independent of Nkx6 regulation and Shh signaling. Neuron 45, 41-53.

Chambers, S. M., Fasano, C. A. Papapetrou, E. P., Tomishima, M., Sadelain, M., and Studer, L. (2009). Highly efficient neural conversion of human ES and iPS cells by dual inhibition of SMAD signaling. Nat. Biotechnol. 27, 275-280.

Chang, C., and Harland, R. M. (2007) Neural induction requires continued suppression of both Smad1 and Smad2 signals during gastrulation. Development 134, 3861-3872.

Chung, S., Shin, B. S., Hedlund, E. Pruszak, J., Ferree, A., Kang, U. J., Isacson, O., and Kim, K. S. (2006). Genetic selection of SOX1GFPexpressing neural precursors removes residual tumorigenic pluripotent stem cells and attenuates tumor formation after transplantation. J. Neurochem. 97, 1467-1480.

Cicchetti, F., Saporta, S., Hauser, R. A., Parent, M., Saint-Pierre, M., Sanberg, P. R., Li, X. J., Parker, J. R., Chu, Y., Mufson, E. J., Kordower, J. H., and Freeman, T. B. (2009). Neural transplants in patients with Huntington's disease undergo disease-like neuronal degeneration. Proc. Natl. Acad. Sci. U.S.A. 106, 12483-12488.

Daadi, M., Maag, A. L., and Steinberg, G. K. (2008). Adherent selfrenewable human embryonic stem cell-derived neural stem cell line: functional engraftment in experimental stroke model. PLoS One 3, e1644. doi: 10.1371/journal.pone.0001644

Dihné, M., Bernreuther, C., Hagel, C., Wesche, K. O., and Schachner,
M. (2006). Embryonic stem cellderived neuronally committed precursor cells with reduced teratoma formation after transplantation into the lesioned adult mouse brain. Stem Cells 24, 1458-1466.

Durston, A. J., Timmermans, J. P., Hage, W. J., Hendriks, H. F., De Vries, N. J., Heideveld, M., and Nieuwkoop, P. D. (1989). Retinoic acid causes an anteroposterior transformation in the developing central nervous system. Nature 340 , 140-144.

Echelard, Y., Epstein, D. J., St-Jacques, B., Shen, L., Mohler, J., Mcmahon, J. A., and Mcmahon, A. P. (1993). Sonic hedgehog, a member of a family of putative signaling molecules, is implicated in the regulation of CNS polarity. Cell 75, 1417-1430.

Erceg, S., Ronaghi, M., Oria, M., Rosello, M. G., Arago, M. A., Lopez, M. G., Radojevic, I., MorenoManzano, V., Rodriguez-Jimenez, F. J., Bhattacharya, S. S., Cordoba, J., and Stojkovic, M. (2010). Transplanted oligodendrocytes and motoneuron progenitors generated from human embryonic stem cells promote locomotor recovery after spinal cord transection. Stem Cells 28, 1541-1549.

Erdö, F., Buhrle, C., Blunk, J., Hoehn, M., Xia, Y., Fleischmann, B., Focking, M., Kustermann, E., Kolossov, E., Hescheler, J., Hossmann, K. A., and Trapp, T. (2003). Host-dependent tumorigenesis of embryonic stem cell transplantation in experimental stroke. J. Cereb. Blood Flow Metab. 23, 780-785.

Fasano, C. A., Chambers, S. M., Lee, G., Tomishima, M. J., and Studer, L. (2010). Efficient derivation of functional floor plate tissue from human embryonic stem cells. Cell Stem Cell 6, 336-347.

Friling, S., Andersson, E., Thompson, L. H., Jonsson, M. E., Hebsgaard, J. B., Nanou, E., Alekseenko, Z., Marklund, U., Kjellander, S., Volakakis, N., Hovatta, O., El Manira, A., Bjorklund, A., Perlmann, T., and Ericson, J. (2009). Efficient production of mesencephalic dopamine neurons by Lmxla expression in embryonic stem cells. Proc. Natl. Acad. Sci. U.S.A. 106, 7613-7618. 
Fukuda, H., Takahashi, J., Watanabe, K., Hayashi, H., Morizane, A., Koyanagi, M., Sasai, Y., and Hashimoto, N. (2006). Fluorescence-activated cell sortingbased purification of embryonic stem cell-derived neural precursors averts tumor formation after transplantation. Stem Cells 24, 763-771.

Gaillard, A., Prestoz, L., Dumartin, B., Cantereau, A., Morel, F., Roger, M., and Jaber, M. (2007). Reestablishment of damaged adult motor pathways by grafted embryonic cortical neurons. Nat. Neurosci. 10, 1294-1299.

Glaser, T., Perez-Bouza, A., Klein, K., and Brüstle, O. (2005). Generation of purified oligodendrocyte progenitors from embryonic stem cells. FASEB J. 19, 112-114.

Gonzalez, M. F., Sharp, F. R., and Loken, J. E. (1988). Fetal frontal cortex transplanted to injured motor/sensory cortex of adult rats: reciprocal connections with host thalamus demonstrated with WGA-HRP. Exp. Neurol. 99, 154-165.

Grigoriadis, N., Lourbopoulos, A., Lagoudaki, R., Frischer, J. M., Polyzoidou, E., Touloumi, O., Simeonidou, C., Deretzi, G., Kountouras, J., Spandou, E., Kotta, K., Karkavelas, G., Tascos, N., and Lassmann, H. (2011). Variable behavior and complications of autologous bone marrow mesenchymal stem cells transplanted in experimental autoimmune encephalomyelitis. Exp. Neurol. 230, 78-89.

Guillaume, D. J., Johnson, M. A., Li, X. J., and Zhang, S. C. (2006). Human embryonic stem cell-derived neural precursors develop into neurons and integrate into the host brain. J. Neurosci. Res. 84, 1165-1176.

Guitet, J., Garnier, C., EbrahimiGaillard, A., and Roger, M. (1994). Efferents of frontal or occipital cortex grafted into adult rat's motor cortex. Neurosci. Lett. 180, 265-268.

Hammerschmidt, M., Brook, A., and Mcmahon, A. P. (1997). The world according to hedgehog. Trends Genet. 13, 14-21.

Harland, R. (2000). Neural induction. Curr. Opin. Genet. Dev. 10, 357-362.

Harris, V. K., Yan, Q. J., Vyshkina, T., Sahabi, S., Liu, X., and Sadiq, S. A. (2012). Clinical and pathological effects of intrathecal injection of mesenchymal stem cell-derived neural progenitors in an experimental model of multiple sclerosis. J. Neurol. Sci. 313, 167-177.
Hemmati-Brivanlou, A., Kelly, O. G., and Melton, D. A. (1994). Follistatin, an antagonist of activin, is expressed in the Spemann organizer and displays direct neuralizing activity. Cell 77, 283-295.

Hedlund, P. B. (2009). The 5-HT7 receptor and disorders of the nervous system: an overview. Psychopharmacology (Berl) 206, 345-354.

Hoehn, M., Küstermann, E., Blunk, J., Wiedermann, D., Trapp, T., Wecker, S., Föcking, M., Arnold, H., Hescheler, J., Fleischmann, B. K., Schwindt, W., and Bührle, C. (2002). Monitoring of implanted stem cell migration in vivo: a highly resolved in vivo magnetic resonance imaging investigation of experimental stroke in rat. Proc. Natl. Acad. Sci. U.S.A. 99, 16267-16272.

Hsieh, J., Aimone, J. B., Kaspar, B. K., Kuwabara, T., Nakashima, K., and Gage, F. H. (2004). IGF-I instructs multipotent adult neural progenitor cells to become oligodendrocytes. J. Cell Biol. 164, 111-122.

Hu, B. Y., Du, Z. W., Li, X. J., Ayala, M., and Zhang, S. C. (2009). Human oligodendrocytes from embryonic stem cells: conserved SHH signaling networks and divergent FGF effects. Development 136, 1443-1452.

Hu, B. Y., Weick, J. P., Yu, J., Ma, L. X., Zhang, X. Q., Thomson, J. A., and Zhang, S. C. (2010). Neural differentiation of human induced pluripotent stem cells follows developmental principles but with variable potency. Proc. Natl. Acad. Sci. U.S.A. 107, 4335-4340.

Hunt, D. P., Irvine, K. A., Webber, D J., Compston, D. A., Blakemore, W. F., and Chandran, S. (2008). Effects of direct transplantation of multipotent mesenchymal stromal/stem cells into the demyelinated spinal cord. Cell Transplant. 17, 865-873.

Hynes, M., Stone, D. M., Dowd, M., Pitts-Meek, S., Goddard, A., Gurney, A., and Rosenthal, A. (1997). Control of cell pattern in the neural tube by the zinc finger transcription factor and oncogene Gli-1. Neuron 19, 15-26.

Inden, M., Kim, D., Gu, Y., Kitamura, Y., Kondo, J., Tsuchiya, D., Taniguchi, T., Shimohama, S., Akaike, A., Sumi, S., and Inoue, K. (2004). Pharmacological characteristics of rotational behavior in hemiparkinsonian rats transplanted with mouse embryonic stem cellderived neurons. J. Pharmacol. Sci. 96, 53-64.

Isacson, O., Wictorin, K., Fischer, W., Sofroniew, M. V., and Bjorklund, A. (1988). Fetal cortical cell suspension grafts to the excitotoxically lesioned neocortex: anatomical and neurochemical studies of trophic interactions. Prog. Brain Res. 78, 13-26.

Itsykson, P., Ilouz, N., Turetsky, T., Goldstein, R. S., Pera, M. F., Fishbein, I., Segal, M., and Reubinoff, B. E. (2005). Derivation of neural precursors from human embryonic stem cells in the presence of noggin. Mol. Cell. Neurosci. 30, 24-36.

Joannides, A. J., Webber, D. J., Raineteau, O., Kelly, C., Irvine, K. A., Watts, C., Rosser, A. E. Kemp, P. J., Blakemore, W. F., Compston, A., Caldwell, M. A. Allen, N. D., and Chandran, S (2007). Environmental signals regulate lineage choice and temporal maturation of neural stem cells from human embryonic stem cells. Brain 130, 1263-1275.

Kang, S. M., Cho, M. S., Seo, H., Yoon, C. J., Oh, S. K., Choi, Y. M., and Kim, D. W. (2007). Efficient induction of oligodendrocytes from human embryonic stem cells. Stem Cells 25, 419-424.

Karumbayaram, S., Novitch, B. G. Patterson, M., Umbach, J. A. Richter, L., Lindgren, A., Conway, A. E., Clark, A. T., Goldman, S A., Plath, K., Wiedau-Pazos, M. Kornblum, H. I., and Lowry, W E. (2009). Directed differentiation of human-induced pluripotent stem cells generates active motor neurons. Stem Cells 27, 806-811.

Karussis, D., Karageorgiou, C., VakninDembinsky, A., Gowda-Kurkalli, B. Gomori, J. M., Kassis, I., Bulte, J. W. Petrou, P., Ben-Hur, T., Abramsky, O., and Slavin, S. (2010). Safety and immunological effects of mesenchymal stem cell transplantation in patients with multiple sclerosis and amyotrophic lateral sclerosis. Arch. Neurol. 67, 1187-1194.

Kawasaki, H., Mizuseki, K., Nishikawa, S., Kaneko, S., Kuwana, Y., Nakanishi, S., Nishikawa, S. I., and Sasai, Y. (2000). Induction of midbrain dopaminergic neurons from ES cells by stromal cell-derived inducing activity. Neuron 28, 31-40.

Keirstead, H. S., Nistor, G., Bernal, G., Totoiu, M., Cloutier, F., Sharp, K., and Steward, O. (2005). Human embryonic stem cell-derived oligodendrocyte progenitor cell transplants remyelinate and restore locomotion after spinal cord injury. J. Neurosci. 25, 4694-4705.

Kelly, C. M., Zietlow, R., Dunnett, S. B., and Rosser, A. E. (2003). The effects of various concentrations of FGF-2 on the proliferation and neuronal yield of murine embryonic neural precursor cells in vitro. Cell Transplant. 12, 215-223.

Kessaris, N., Fogarty, M., Iannarelli, P., Grist, M., Wegner, M., and Richardson, W. D. (2006). Competing waves of oligodendrocytes in the forebrain and postnatal elimination of an embryonic lineage. Nat. Neurosci. 9, 173-179.

Kessaris, N., Jamen, F., Rubin, L. L., and Richardson, W. D. (2004). Cooperation between sonic hedgehog and fibroblast growth factor/MAPK signalling pathways in neocortical precursors. Development 131, 1289-1298.

Kim, J. H., Auerbach, J. M., RodríguezGómez, J. A., Velasco, I., Gavin, D., Lumelsky, N., Lee, S. H., Nguyen, J., Sánchez-Pernaute, R., Bankiewicz, K., and McKay, R. (2002). Dopamine neurons derived from embryonic stem cells function in an animal model of Parkinson's disease. Nature 418, 50-56.

Kokovay, E., Shin, Q., and Temple, S. (2008). The incredible elastic brain: how neural stem cells expand our minds. Neuron 60, 420-429.

Kondziolka, D., Steinberg, G. K., Wechsler, L., Meltzer, C. C., Elder E., Gebel, J., Decesare, S., Jovin, T., Zafonte, R., Lebowitz, J., Flickinger, J. C., Tong, D., Marks, M. P., Jamieson, C., Luu, D. Bell-Stephens, T., and Teraoka, J. (2005). Neurotransplantation for patients with subcortical motor stroke: a phase 2 randomized trial. J. Neurosurg. 103, 38-45.

Kondziolka, D., Wechsler, L., Goldstein, S., Meltzer, C., Thulborn, K. R., Gebel, J., Jannetta, P., DeCesare, S., Elder, E. M., McGrogan, M., Reitman, M. A., and Bynum, L. (2000). Transplantation of cultured human neuronal cells for patients with stroke. Neurology 55, 565-569.

Kriks, S., Shim, J. W., Piao, J., Ganat, Y. M., Wakeman, D. R., Xie, Z., Carrillo-Reid, L., Auyeung, G. Antonacci, C., Buch, A., Yang, L., Beal, M. F., Surmeier, D. J. Kordower, J. H., Tabar, V., and Studer, L. (2011). Dopamine neurons derived from human ES cells efficiently engraft in animal models of Parkinson's disease. Nature 480, 547-551.

Krystkowiak, P., Gaura, V., Labalette, M., Rialland, A., Remy, P., Peschanski, M., and Bachoud-Lévi, A. C. (2007). Alloimmunisation to donor antigens and immune rejection following foetal neural grafts to the brain in patients with Huntington's disease. PLoS One 2, e166. doi: 10.1371/journal. pone.0000166 
Lachapelle, F., Avellana-Adalid, V., Nait-Oumesmar, B., and Baron-Van Evercooren, A. (2002). Fibroblast growth factor-2 (FGF-2) and platelet-derived growth factor $\mathrm{AB}$ (PDGF AB) promote adult SVZderived oligodendrogenesis in vivo. Mol. Cell. Neurosci. 20, 390-403.

Lamb, T. M., Knecht, A. K., Smith, W. C., Stachel, S. E., Economides, A. N., Stahl, N., Yancopolous, G. D., and Harland, R. M. (1993). Neural induction by the secreted polypeptide noggin. Science 262, 713-718.

Lassmann, H. (2009). Clinical and pathological topics of multiple sclerosis. Rinsho Shinkeigaku 49, 715-718.

Lee, H., Shamy, G. A., Elkabetz, Y., Schofield, C. M., Harrsion, N. L., Panagiotakos, G., Socci, N. D., Tabar, V., and Studer, L. (2007). Directed differentiation and transplantation of human embryonic stem cell-derived motoneurons. Stem Cells 25, 1931-1939.

Lee, J. J., Von Kessler, D. P., Parks, S., and Beachy, P. A. (1992). Secretion and localized transcription suggest a role in positional signaling for products of the segmentation gene hedgehog. Cell 71, 33-50.

Lee, S. H., Lumelsky, N., Studer, L., Auerbach, J. M., and McKay, R. D. (2000). Efficient generation of midbrain and hindbrain neurons from mouse embryonic stem cells. Nat. Biotechnol. 18, 675-679.

Letinic, K., Zoncu, R., and Rakic, P. (2002). Origin of GABAergic neurons in the human neocortex. Nature 417, 645-649.

Li, X. J., Hu, B. Y., Jones, S. A., Zhang, Y. S., Lavaute, T., Du, Z. W., and Zhang, S. C. (2008). Directed differentiation of ventral spinal progenitors and motor neurons from human embryonic stem cells by small molecules. Stem Cells 26, 886-893.

Li, X. J., Zhang, X., Johnson, M. A., Wang, Z. B., Lavaute, T., and Zhang, S. C. (2009). Coordination of sonic hedgehog and Wnt signaling determines ventral and dorsal telencephalic neuron types from human embryonic stem cells. Development 136, 4055-4063.

Liguori, G. L., Echevarria, D., Bonilla, S., D'Andrea, D., Liguoro, A., Persico, M. G., and Martinez, S. (2009). Characterization of the functional properties of the neuroectoderm in mouse Cripto $(-/-)$ embryos showing severe gastrulation defects. Int. J. Dev. Biol. 53, 549-557.

Lindvall, O., and Björklund, A. (2011). Cell therapeutics in Parkinson's disease. Neurotherapeutics 8, 539-548.
Linker, C., and Stern, C. D. (2004). Neural induction requires BMP inhibition only as a late step, and involves signals other than FGF and Wnt antagonists. Development 131, 5671-5681.

Liu, H., and Zhang, S. C. (2010). Specification of neuronal and glial subtypes from human pluripotent stem cells. Cell. Mol. Life Sci. 68 , 3995-4008.

Liu, S., Qu, Y., Stewart, T. J., Howard, M. J., Chakrabortty, S., Holekamp, T. F., and Mcdonald, J. W. (2000). Embryonic stem cells differentiate into oligodendrocytes and myelinate in culture and after spinal cord transplantation. Proc. Natl. Acad. Sci. U.S.A. 97, 6126-6131.

Lowell, S., Benchoua, A., Heavey, B., and Smith, A. G. (2006). Notch promotes neural lineage entry by pluripotent embryonic stem cells. PLoS Biol. 4, e121. doi: 10.1371/journal.pbio.0040121

Lupo, G., Harris, W. A., and Lewis, K. E. (2006). Mechanisms of ventral patterning in the vertebrate nervous system. Nat. Rev. Neurosci. 7 , 103-114.

Martinat, C., Bacci, J. J., Leete, T., Kim, J., Vanti, W. B., Newman, A. H., Cha, J. H., Gether, U., Wang, H., and Abeliovich, A. (2006). Cooperative transcription activation by Nurr 1 and Pitx 3 induces embryonic stem cell maturation to the midbrain dopamine neuron phenotype. Proc. Natl. Acad. Sci. U.S.A. 103, 2874-2879.

Meltzer, C. C., Kondziolka, D., Villemagne, V. L., Wechsler, L., Goldstein, S., Thulborn, K. R., Gebel, J., Elder, E. M., DeCesare, S., and Jacobs, A. (2001). Serial $[18 \mathrm{~F}]$ fluorodeoxyglucose positron emission tomography after human neuronal implantation for stroke. Neurosurgery 49, 586-591.

Mitjavila-Garcia, M. T., Simonin, C., and Peschanski, M. (2005). Embryonic stem cells: meeting the needs for cell therapy. Adv. Drug Deliv. Rev. 57, 1935-1943.

Mohyeddin Bonab, M., Yazdanbakhsh, S., Lotfi, J., Alimoghaddom, K., Talebian, F., Hooshmand, F., Ghavamzadeh, A., and Nikbin, B. (2007). Does mesenchymal stem cell therapy help multiple sclerosis patients? Report of a pilot study. Iran J. Immunol. 4, 50-57.

Molotkova, N., Molotkov, A., Sirbu, I. O., and Duester, G. (2005). Requirement of mesodermal retinoic acid generated by Raldh2 for posterior neural transformation. Mech. Dev. 122, 145-155.
Moyse, E., Segura, S., Liard, O., Mahaut, S., and Mechawar, N. (2008). Microenvironmental determinants of adult neural stem cell proliferation and lienage commitment on the healthy and injured central nervous system. Curr. Stem Cell Res. Ther. 3, 163-184.

Muramatsu, S., Okuno, T., Suzuki, Y., Nakayama, T., Kakiuchi, T., Takino, N., Iida, A., Ono, F., Terao, K. Inoue, N., Nakano, I., Kondo, Y., and Tsukada, H. (2009). Multitracer assessment of dopamine function after transplantation of embryonic stem cell-derived neural stem cells in a primate model of Parkinson's disease. Synapse 63, 541-548.

Navé, B. T., Ouwens, M., Withers, D. J., Alessi, D. R., and Shepherd, P. R. (1999). Mammalian target of rapamycin is a direct target for protein kinase B. J. Neurosci. 2 , 427-431.

Nelson, P. T., Kondziolka, D., Wechsler, L., Goldstein, S., Gebel, J., DeCesare, S., Elder, E. M., Zhang, P. J., Jacobs, A., McGrogan, M., Lee, V. M., and Trojanowski, J. Q. (2002). Clonal human (hNT) neuron grafts for stroke therapy: neuropathology in a patient 27 months after implantation Am. J. Pathol. 160, 1201-1206.

Nicolay, D. J., Doucette, J. R., and Nazarali, A. J. (2007). Transcriptional control of oligodendrogenesis. Glia 55, 1287-1299.

Nicoleau, C., Viegas, P., Perrier, A. and Peschanski, M. (2011). Human pluripotent stem cell therapy for Huntington's disease: technical, immunological, and safety challenges. Neurotherapeutics 8 , 562-576.

Nistor, G. I., Totoiu, M. O., Haque, N., Carpenter, M. K., and Keirstead, H. S. (2005). Human embryonic stem cells differentiate into oligodendrocytes in high purity and myelinate after spinal cord transplantation. Glia 49, 385-396.

Nori, S., Okada, Y., Yasuda, A., Tsuji, O., Takahashi, Y., Kobayashi, Y., Fujiyoshi, K., Koike, M., Uchiyama, Y., Ikeda, E., Toyama, Y., Yamanaka, S., Nakamura, M., and Okano, H. (2011). Grafted human-induced pluripotent stem-cell-derived neurospheres promote motor functional recovery after spinal cord injury in mice. Proc. Natl. Acad. Sci. U.S.A. 108, 16825-16830.

Ogura, T., and Evans, R. M. (1995). A retinoic acid-triggered cascade of HOXB1 gene activation. Proc. Natl. Acad. Sci. U.S.A. 92, 387-391.

Olsson, M., Bjorklund, A., and Campbell, K. (1998). Early specification of striatal projection neurons and interneuronal subtypes in the lateral and medial ganglionic eminence. Neuroscience 84, 867-876

Ono, Y., Nakatani, T., Sakamoto, Y., Mizuhara, E., Minaki, Y., Kumai, M., Hamaguchi, A., Nishimura, M., Inoue, Y., Hayashi, H., Takahashi, J., and Imai, T. (2007). Differences in neurogenic potential in floor plate cells along an anteroposterior location: midbrain dopaminergic neurons originate from mesencephalic floor plate cells. Development 134, 3213-3225.

Onteniente, B., and Polentes, J. (2011). Regenerative medicine for stroke are we there yet? Cerebrovasc. Dis. 31, 544-551.

Owada, Y., Utsunomiya, A., Yoshimoto, T., and Kondo, H. (1997) Expression of mRNA for Akt, serine-threonine protein kinase, in the brain during development and its transient enhancement following axotomy of hypoglossal nerve. J. Mol. Neurosci. 9, 27-33.

Papalopulu, N., Clarke, J. D., Bradley, L., Wilkinson, D., Krumlauf, R., and Holder, N. (1991). Retinoic acid causes abnormal development and segmental patterning of the anterior hindbrain in Xenopus embryos. Development 113, 1145-1158.

Perrier, A. L., Tabar, V., Barberi, T. Rubio, M. E., Bruses, J., Topf, N., Harrison, N. L., and Studer, L. (2004). Derivation of midbrain dopamine neurons from human embryonic stem cells. Proc. Natl. Acad. Sci. U.S.A. 101, 12543-12548.

Piccini, P., Brooks, D. J., Björklund, A., Gunn, R. N., Grasby, P. M., Rimoldi, O., Brundin, P., Hagell, P., Rehncrona, S., Widner, H., and Lindvall, O. (1999). Dopamine release from nigral transplants visualized in vivo in a Parkinson's patient. Nat. Neurosci. $2,1137-1140$

Pombero, A., and Martinez, S. (2009). Telencephalic morphogenesis during the process of neurulation: an experimental study using quailchick chimeras. J. Comp. Neurol. 512, 784-797.

Quinones-Hinojosa, A., and Chaichana, K. (2007). The human subventricular zone: a source of new cells and a potential source of brain tumors. Exp. Neurol. 205, 313-324.

Rallu, M., Corbin, J. G., and Fishell, G. (2002). Parsing the prosencephalon. Nat. Rev. Neurosci. 3, 943-951.

Ray, J., Baird, A., and Gage, F. H. (1997). A 10-amino acid sequence of fibroblast growth factor 2 is 
sufficient for its mitogenic activity on neural progenitor cells. Proc. Natl. Acad. Sci. U.S.A. 94, 7047-7070.

Rhee, Y. H., Ko, J. Y., Chang, M. Y., Yi, S. H., Kim, D., Kim, C. H., Shim, J. W., Jo, A. Y., Kim, B. W., Lee, H., Lee, S. H., Suh, W., Park, C. H., Koh, H. C., Lee, Y. S., Lanza, R., Kim, K. S., and Lee, S. H. (2011). Proteinbased human iPS cells efficiently generate functional dopamine neurons and can treat a rat model of Parkinson disease. J. Clin. Invest. 121, 2326-2335.

Rossi, F., and Cattaneo, E. (2002). Opinion: neural stem cell therapy for neurological diseases: dreams and reality. Nat. Rev. Neurosci. 3, 401-409.

Rossig, L., Jadidi, A. S., Urbich, C., Badorff, C., Zeiher, A. M., and Dimmeler, S. (2001). Aktdependent phosphorylation of p21(Cip1) regulates PCNA binding and proliferation of endothelial cells. Mol. Cell. Biol. 21, 5644-5657.

Roy, N. S., Cleren, C., Singh, S. K., Yang, L., Beal, M. F., and Goldman, S. A. (2006). Functional engraftment of human ES cell-derived dopaminergic neurons enriched by coculture with telomerase-immortalized midbrain astrocytes. Nat. Med. 12, 1259-1268.

Ruiz i Altaba, A. (1998). Combinatorial Gli gene function in floor plate and neuronal inductions by Sonic hedgehog. Development 125, 2203-2212.

Seminatore, C., Polentes, J., Ellman, D., Kozubenko, N., Itier, V., Tine, S., Tritschler, L., Brenot, M., Guidou, E., Blondeau, J., Lhuillier, M., Bugi, A., Aubry, L., Jendelova, P., Sykova, E., Perrier, A. L., Finsen, B., and Onteniente, B. (2010). The postischemic environment differentially impacts teratoma or tumor formation after transplantation of human embryonic stem cell-derived neural progenitors. Stroke 41, 153-159.

Sharp, F. R., Jickling, G. C., Stamova, B., Tian, Y., Zhan, X., Liu, D., Kuczynski, B., Cox, C. D., and Ander, B. P. (2011). Molecular markers and mechanisms of stroke: RNA studies of blood in animals and humans. J. Cereb. Blood Flow Metab. 31, 1513-1531.

Sheen, V. L., Arnold, M. W., Wang, Y., and Macklis, J. D. (1999). Neural precursor differentiation following transplantation into neocortex is dependent on intrinsic developmental state and receptor competence. Exp. Neurol. 158, 47-62.
Shin, S., Dalton, S., and Stice, S. L. (2005). Human motor neuron differentiation from human embryonic stem cells. Stem Cells Dev. 14, 266-269.

Siatskas, C., Payne, N. L., Short, M. A., and Bernard, C. C. (2010). A consensus statement addressing mesenchymal stem cell transplantation for multiple sclerosis: it's time! Stem Cell Rev. 6, 500-506.

Sierra, A., Encinas, J. M., and MaleticSavatic, M. (2011). Adult human neurogenesis: from microscopy to magnetic resonance imaging. Front. Neurosci. 4, 47. doi: 10.3389/fnins.2011.00047

Sinor, A. D., and Lillien, L. (2004). Akt-1 expression level regulates CNS precursors. J. Neurosci. 24 8531-8541.

Smith, W. C., and Harland, R. M. (1992). Expression cloning of noggin, a new dorsalizing factor localized to the Spemann organizer in Xenopus embryos. Cell 70, 829-840.

Sonntag, K. C, Pruszak, J., Yoshizaki, T., van Arensbergen, J., SanchezPernaute, R., and Isacson, O. (2007). Enhanced yield of neuroepithelial precursors and midbrain-like dopaminergic neurons from human embryonic stem cells using the bone morphogenic protein antagonist noggin. Stem Cells 25, 411-418.

Sorensen, J. C., Grabowski, M., Zimmer, J., and Johansson, B. B. (1996). Fetal neocortical tissue blocks implanted in brain infarcts of adult rats interconnect with the host brain. Exp. Neurol. 138, 227-235.

Soula, C., Danesin, C., Kan, P., Grob, M., Poncet, C., and Cochard, P. (2001). Distinct sites of origin of oligodendrocytes and somatic motoneurons in the chick spinal cord: oligodendrocytes arise from $\mathrm{Nkx} 2.2$-expressing progenitors by a Shh-dependent mechanism. Development 128, 1369-1379.

Soundararajan, P., Miles, G. B., Rubin, L. L., Brownstone, R. M., and Rafuse, V. F. (2006). Motoneurons derived from embryonic stem cells express transcription factors and develop phenotypes characteristic of medial motor column neurons. J. Neurosci. 26 3256-3268.

Stamataki, D., Ulloa, F., Tsoni, S. V., Mynett, A., and Briscoe, J. (2005). A gradient of Gli activity mediates graded Sonic Hedgehog signaling in the neural tube. Genes Dev. 19, 626-641.
Sundberg, M., Skottman, H., Suuronen, R., and Narkilahti, S. (2011). Production and isolation of NG2+ oligodendrocyte precursors from human embryonic stem cells in defined serumfree medium. Stem Cell Res. 5, 91-103.

Swistowski, A., Peng, J., Liu, Q., Mali, P., Rao, M. S., Cheng, L., and Zeng, X. (2011). Efficient generation of functional dopaminergic neurons from human induced pluripotent stem cells under defined conditions. Stem Cells 28 1893-1904.

Tabar, V., Panagiotakos, G., Greenberg, E. D., Chan, B. K., Sadelain, M., Gutin, P. H., and Studer, L. (2005). Migration and differentiation of neural precursors derived from human embryonic stem cells in the rat brain. Nat. Biotechnol. 23 , 601-606.

Takahashi, K., and Yamanaka, S (2006). Induction of pluripotent stem cells from mouse embryonic and adult fibroblast cultures by defined factors. Cell 126, 663-676.

Tashiro, S., Michiue, T., Higashijima, S. Zenno, S., Ishimaru, S., Takahashi, F., Orihara, M., Kojima, T., and Saigo, K. (1993). Structure and expression of hedgehog, a Drosophila segmentpolarity gene required for cell-cell communication. Gene 124, 183-189.

Tavazoie, M., Van der Veken, L., SilvaVargas, V., Louissaint, M., Colonna, L., Zaidi, B., Garcia-Verdugo, J. M. and Doetsch, F. (2008). A specialized vascular niche for adult neural stem cells. Cell Stem Cell 3, 279-288.

Thomson, J. A., Itskovitz-Eldor, J., Shapiro, S. S., Waknitz, M. A., Swiergiel, J. J., Marshall, V. S., and Jones, J. M. (1998). Embryonic stem cell lines derived from human blastocysts. Science 282, 1145-1147.

Vallstedt, A., Klos, J. M., and Ericson, J. (2005). Multiple dorsoventral origins of oligodendrocyte generation in the spinal cord and hindbrain. Neuron 45, 55-67.

Vieira, C., Pombero, A., Garcia-Lopez, R., Gimeno, L., Echevarria, D. and Martinez, S. (2010). Molecular mechanisms controlling brain development: an overview of neuroepithelial secondary organizers. Int. J. Dev. Biol. 54, 7-20.

Watanabe, K., Kamiya, D., Nishiyama, A., Katayama, T., Nozaki, S. Kawasaki, H., Watanabe, Y., Mizuseki, K., and Sasai, Y. (2005). Directed differentiation of telencephalic precursors from embryonic stem cells. Nat. Neurosci. 8, 288-296.

Wernig, M., Benninger, F., Schmandt, T., Rade, M., Tucker, K. L., Büssow, H., Beck, H., and Brüstle, O. (2004). Functional integration of embryonic stem cell-derived neurons in vivo. J. Neurosci. 24, 5258-5268.

Wictorin, K., Ouimet, C. C., and Bjorklund, A. (1989). Intrinsic organization and connectivity of intrastriatal striatal transplants in rats as revealed by DARPP-32 immunohistochemistry: specificity of connections with the lesioned host brain. Eur. J. Neurosci. 1, 690-701.

Yamout, B., Hourani, R., Salti, H., Barada, W., El-Haji, T., Al-Kutoubi, A., Herlopian, A., Baz, E. K. Mahfouz, R., Khalil-Hamdan, R., Kreidieh, N. M., El-Sabban, M., and Bazarbachi, A. (2010). Bone marrow mesenchymal stem cell transplantation in patients with multiple sclerosis: a pilot study. J. Neuroimmunol. 227, 185-189.

Yasuda, A., Tsuji, O., Shibata, S., Nori, S., Takano, M., Kobayashi, Y., Takahashi, Y., Fujiyoshi, K. Hara, C. M., Miyawaki, A., Okano, H. J., Toyama, Y., Nakamura, M., and Okano, H. (2011). Significance of remyelination by neural stem/progenitor cells transplanted into the injured spinal cord. Stem Cells 29, 1983-1994.

Ye, W., Shimamura, K., Rubenstein, J. L., Hynes, M. A., and Rosenthal, A. (1998). FGF and Shh signals control dopaminergic and serotonergic cell fate in the anterior neural plate. Cell 93, 755-766.

Ying, Q. L., Stavridis, M., Griffiths, D., Li, M., and Smith, A. (2003). Conversion of embryonic stem cells into neuroectodermal precursors in adherent monoculture. Nat Biotechnol. 21, 183-186.

Zeng, H., Guo, M., Martins-Taylor, K., Wang, X., Zhang, Z., Park, J. W., Zhan, S., Kronenberg, M. S., Lichtler, A., Liu, H. X., Chen, F. P., Yue, L., Li, X. J., and $\mathrm{Xu}, \mathrm{R}$ H. (2010). Specification of regionspecific neurons including forebrain glutamatergic neurons from human induced pluripotent stem cells. PLoS One 5, e11853. doi: 10.1371/journal.pone.0011853

Zervas, M., Millet, S., Ahn, S., and Joyner, A. L. (2004). Cell behaviors and genetic lineages of the mesencephalon and rhombomere 1 . Neuron 43, 345-357.

Zhang, S. C., Ge, B., and Duncan, I. D. (1999). Adult brain retains 
the potential to generate oligodendroglial progenitors with extensive myelination capacity. Proc. Natl. Acad. Sci. U.S.A. 96, 4089-4094.

Zhang, S. C., Wernig, M., Duncan, I. D., Brüstle, O., and Thomson, J. A. (2001). In vitro differentiation of transplantable neural precursors from human embryonic stem cells. Nat. Biotechnol. 19, 1129-1133.

Zhao, C., Deng, W., and Gage, F. H. (2008). Mechanisms and functional implications of adult neurogenesis. Cell 132, 645-660.

Zimmerman, L. B., De Jesus-Escobar, J. M., and Harland, R. M. (1996). The Spemann organizer signal noggin binds and inactivates bone morphogenetic protein 4. Cell 86, 599-606.

Conflict of Interest Statement: The authors declare that the research was conducted in the absence of any commercial or financial relationships that could be construed as a potential conflict of interest.

Received: 01 December 2011; paper pending published: 22 December 2011; accepted: 09 January 2012; published online: 27 January 2012.

Citation: Benchoua A and Onteniente B (2012) Intracerebral transplantation for neurological disorders. Lessons from developmental, experimental, and clinical studies. Front. Cell. Neurosci. 6:2. doi: 10.3389/fncel.2012.00002

Copyright (c) 2012 Benchoua and Onteniente. This is an open-access article distributed under the terms of the Creative Commons Attribution Non Commercial License, which permits non-commercial use, distribution, and reproduction in other forums, provided the original authors and source are credited. 